\title{
Central giant cell granuloma of the maxilla
}

\author{
Manish Gupta, ${ }^{1}$ Monica Gupta, ${ }^{2}$ Sunder Singh, ${ }^{1}$ Rupinder Kaur ${ }^{3}$
}

\begin{abstract}
${ }^{1}$ Department of Otorhinolaryngology, Gian Sagar Medical College, Chandigarh, India ${ }^{2}$ Department of Medicine, Government Medical College and Hospital, Chandigarh, India

${ }^{3}$ Department of Pathology, Gian Sagar Medical College, Patiala, Punjab, India
\end{abstract}

\section{Correspondence to}

Dr Monica Gupta, monicamanish2001@gmail. com

\footnotetext{
To cite: Gupta $M$, Gupta M, Singh S, et al. BMJ Case Rep Published online: [please include Day Month Year] doi:10.1136/ bcr-2013-009102
}

\begin{abstract}
SUMMARY
Central giant cell granuloma (CGCG), formerly called giant cell reparative granuloma, is a non-neoplastic proliferative lesion of an unknown aetiology. It occurs most commonly in the mandible. The case reported here resembled a wide variety of conditions that led to a misdiagnosis both on clinical and radiographic examinations but was histopathologically diagnosed as CGCG. We managed this case by endoscopic excision and curettage via nasal route without producing external scar and avoiding damage to the un-erupted tooth.
\end{abstract}

\section{BACKGROUND}

Central giant cell granuloma (CGCG) as described by Jaffe in 1953 is an idiopathic non-neoplastic proliferative intraosseous lesion consisting of cellular fibrous tissue that contains multiple foci of haemorrhage, aggregations of multinucleated giant cells and occasionally trabeculae of woven bone. ${ }^{12}$ Initially, the term giant cell reparative granuloma was used, but now abandoned since the lesion represents essentially a destructive process. ${ }^{3}$

\section{CASE PRESENTATION}

A 9-year-old male patient presented to our out patient department with a swelling on the left side of his face since 8 months. The swelling was reported to be insidious in onset, gradually progressive, with associated left nasal obstruction and discharge. There was no history of loosening of teeth, nasal bleed and difficulty in chewing or swallowing or decreased vision. There was no history of preceding trauma, fever, headache or similar swelling.

External examination revealed a diffuse swelling on the left side of his face causing obliteration of nasolabial fold, mild proptosis of left eye and facial asymmetry. The overlying skin was normal, nontender and there was no associated lymphadenopathy. The intraoral examination revealed primary dentition in place with swelling in the left upper alveolus, obliterating the gingivobuccal sulcus and bulge on the left side of hard palate. The surface was smooth without fluctuation or bony crepitus.

\section{INVESTIGATIONS}

A CT in coronal and axial sections of left maxillary sinus showed a large expansile mainly cystic lesion, $48 \mathrm{~mm} \times 36 \mathrm{~mm} \times 35 \mathrm{~mm}$ in size causing thinning and erosion of all the walls (figure 1). A soft tissue mass was seen along its posteromedial wall showing mild enhancement on postcontrast scan. Destruction of medial wall of maxillary sinus and projection of mass into left nasal cavity was seen (figure 2). Anterosuperiorly the lesion was bulging

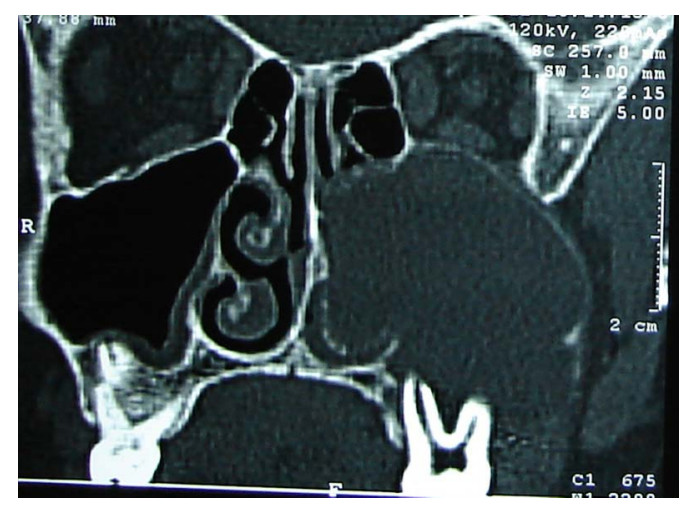

Figure 1 Coronal section CT showing large, expansile, cystic lesion of the left maxillary sinus obliterating the left nasal cavity with erosion of left inferior and middle turbinate and inferiorly erosion of alveolus.

into the left orbit causing mild obliteration of the retrobulbar fat and leading to mild proptosis of the eyeball. Laterally the lesion was bulging into the left infratemporal fossa and posteriorly into pterygopalatine fossa. Inferiorly there was erosion of the alveolar arch with projection of teeth into the cystic component. The biochemical and haematological investigations of the patient were all within normal limits. Brown tumour of hyperparathyroidism was excluded by demonstrating normal levels of serum calcium, phosphorus and alkaline phosphatase.

\section{DIFFERENTIAL DIAGNOSIS}

Various clinical differentials were considered in this patient, importantly maxillary mucocoele, giant cell tumour, radicular cyst, adenomatoid odontogenic tumour and ameloblastoma.

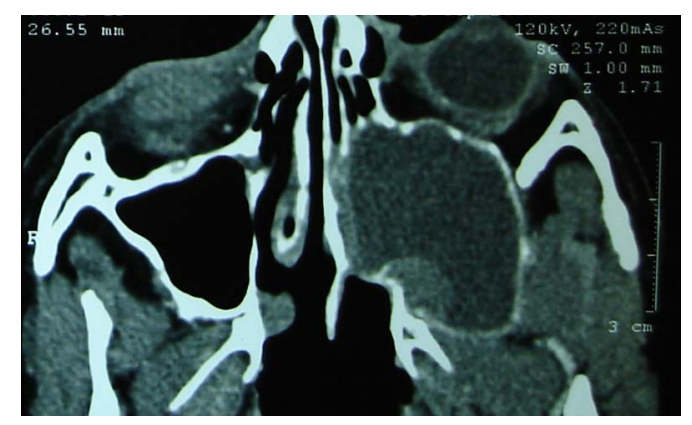

Figure 2 Axial section CT with contrast showing same cystic lesion of the left maxilla with soft tissue density component along posteromedial wall with mild enhancement and left orbital extension causing left proptosis. 


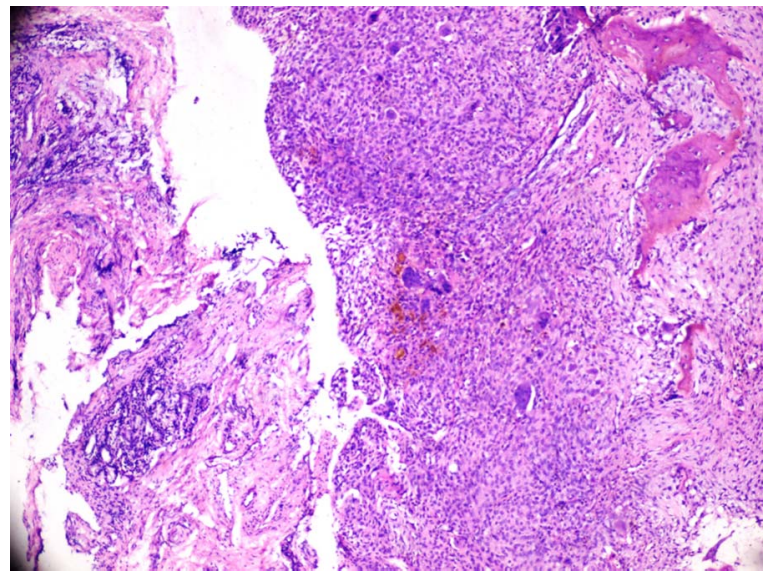

Figure 3 Histopathology slide showing loose oedematous cellular stroma with multinucleated giant cells. $(H \& E, \times 10)$.

\section{TREATMENT}

The cystic mass was excised via transnasal, middle meatal route endoscopically, including a small solid portion lying against posterior wall of maxilla. First the cyst was decompressed by removing approximately. $20 \mathrm{ml}$ serosanguinous fluid, and then the thickened cyst wall was lifted from the bony walls and removed completely. The bony wall remnants were curetted. The nasal cavity was packed with medicated ribbon gauze for $48 \mathrm{~h}$ and perioperative period was uneventful.

Histopathological examination revealed pseudostratified ciliated epithelium with loose oedematous cellular stroma with patchy distribution of multinucleated giant cells, focal new bone formation and areas of haemorrhage resting focally on periosteum. All these features suggested giant cell granuloma (figure 3).

\section{OUTCOME AND FOLLOW-UP}

The patient recovered well in the postoperative period. In the last one year's follow-up, there has not been any recurrence. The bony expansion of the left maxilla also subsided and facial profile became almost normal.

\section{DISCUSSION}

Central giant cell granuloma is a non-neoplastic proliferative lesion of an unknown aetiology. It occurs most commonly in the mandible than in maxilla. Also, it is more common on the right than the left side with females having more predilection than males in the ratio $2: 1 .^{4}$ This is totally in contrast with our case, wherein left maxilla was involved in a male child. It rarely may involve bones other than those of the craniofacial region. The peripheral variety presents as pedunculated or sessile lesions on the gingiva while central lesions are endosteal. Though trauma has been considered as an important aetiological factor in the initiation of this lesion, but the history of trauma was absent in this case. The lesions increase by accumulation of tissue which is produced by slow, minute, continuous haemorrhages of multicentric nature because of trauma and some defect in the capillaries. ${ }^{6}$

The giant cell granuloma is often confused with giant cell tumour. However, the giant cell tumour occurs in the age range 25-40 years, involves long bones and is more aggressive in nature with frequent recurrence after curettage. Microscopically, the giant cells are osteoclastic and almost uniformly distributed, whereas in giant cell granuloma, foreign body type giant cells with irregular distribution and vacuolation are seen. The stroma in giant cell granuloma is collagenised or oedematous, whereas in giant cell tumour the stroma is made up of plump tumour cells.

A diagnosis of CGCG is based on histopathology. This statement is further supported by our case which presented with clinical features leading to differential diagnoses of conditions such as radicular cyst, adenomatoid odontogenic tumour, calcifying epithelial odontogenic cyst desmoplastic ameloblastoma and fibrous dysplasia. ${ }^{6}$

The most common presenting sign of CGCG is a painless swelling with noticeable facial asymmetry. The radiological appearance may be unilocular or multilocular radiolucency, with expansion and destruction of surrounding bone.

The recurrence rate is reported to be $13-22 \%$ with mostly manifesting within first 2 years postoperatively. ${ }^{7}$ Generally, curettage of well-defined localised lesions is associated with a low rate of recurrence but in extensive lesions with evidence of perforation of cortex, more radical excision is mandatory, which may lead to loss of teeth. In recent years, medical treatment including intralesional corticosteroid injection or calcitonin injection has been advocated in addition to surgery. ${ }^{8} 9$

\section{Learning points}

- The central giant cell granuloma of the jaw presents as a painless, solitary radiolucent mass, often difficult to diagnose purely on clinical basis.

- The authors suggest the transnasal endoscopic route for excision of such upper jaw lesions especially in children. Besides providing a good surgical access and better illumination, this approach saves the non-erupted teeth germs from damage.

\section{Competing interests None.}

Patient consent Obtained.

Provenance and peer review Not commissioned; externally peer reviewed.

\section{REFERENCES}

1 De Lange J, Van den A. Clinical and radiological features of central giant cell lesions of the jaw. Oral Surg Oral Med Oral Pathol Oral Radiol Endod 2005:99:464-70.

2 Kaffe I, Ardkian L, Taicher S, et al. Radiologic features of central giant cell granuloma of the jaws. Oral Surg Oral Med Oral Pathol Oral Radiol Endod 1996;81:720-6.

3 Cohen MA, Hertzanu Y. Radiologic features, including those seen with computed tomography of central giant cell granuloma of the jaws. Oral Surg Oral Med Oral Pathol 1988;65:255-61.

4 Sidhu MS, Parkash H, Sidhu SS. Central giant cell granuloma of jaws-review of 19 cases. Br J Oral Maxillofac Surg 1995;33:43-6.

5 Curtis NJ, Walker DM. A case of aggressive multiple metachronous central giant cell granulomas of the jaws: differential diagnosis and management options. Int J Oral Maxillofac Surg 2005;34:806-8.

6 Ebrahimi H, Yazdani J, Pourshahidi S, et al. Central giant cell granuloma of the posterior maxilla: a case report. J Dent Res Dent Clin Dent Prospects 2008;2:71-5.

7 Walstad WR, Fields T, Schow SR, et al. Expansile lesion of the anterior maxilla. J Oral Maxillofac Surg 1999;57:595-9.

8 Sezer B, Koyuncu B, Gomel M, et al. Intralesional corticosteroid injection for central giant cell granuloma: a case report and review of the literature. Turk J Pediatr 2005; $47: 75-81$.

9 Harris M. Central giant cell granulomas regress with calcitonin therapy. $\mathrm{Br} J$ Oral Maxillofac Surg 1993;31:89-94. 
Copyright 2013 BMJ Publishing Group. All rights reserved. For permission to reuse any of this content visit http://group.bmj.com/group/rights-licensing/permissions.

BMJ Case Report Fellows may re-use this article for personal use and teaching without any further permission.

Become a Fellow of BMJ Case Reports today and you can:

- Submit as many cases as you like

- Enjoy fast sympathetic peer review and rapid publication of accepted articles

- Access all the published articles

- Re-use any of the published material for personal use and teaching without further permission

For information on Institutional Fellowships contact consortiasales@bmjgroup.com

Visit casereports.bmj.com for more articles like this and to become a Fellow 